\title{
Environmental Influences on Young Adult Male Height. A Comparison of Town and Countryside in the Netherlands, $1815-1900$
}

Jan Kok, Erik Beekink \& David Bijsterbosch

To cite this article: Kok, J., Beekink, E., \& Bijsterbosch, D. (2017). Environmental Influences on Young Adult Male Height. A Comparison of Town and Countryside in the Netherlands, 1815-1900. Historical Life Course Studies, 6, 95-110. http://hdl. handle.net/10622/23526343-2017-0010?locatt=view:master

\section{HISTORICAL LIFE COURSE STUDIES}

Urban-rural dichotomies in historical demography

VOLUME 6, SPECIAL ISSUE 1 2018

GUEST EDITORS

Christa Matthys Saskia Hin Jan Kok Richard Paping

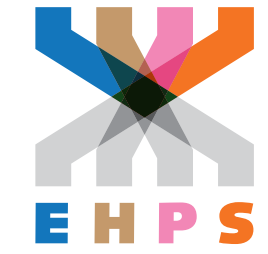




\section{HISTORICAL LIFE COURSE STUDIES}

Historical Life Course Studies is the electronic journal of the European Historical Population Samples Network (EHPSNet). The journal is the primary publishing outlet for research involved in the conversion of existing European and nonEuropean large historical demographic databases into a common format, the Intermediate Data Structure, and for studies based on these databases. The journal publishes both methodological and substantive research articles.

\section{Methodological Articles}

This section includes methodological articles that describe all forms of data handling involving large historical databases, including extensive descriptions of new or existing databases, syntax, algorithms and extraction programs. Authors are encouraged to share their syntaxes, applications and other forms of software presented in their article, if pertinent, on the EHPS-Net website.

\section{Research articles}

This section includes substantive articles reporting the results of comparative longitudinal studies that are demographic and historical in nature, and that are based on micro-data from large historical databases.

Historical Life Course Studies is a no-fee double-blind, peer-reviewed open-access journal supported by the European Science Foundation (ESF, http://www.esf.org), the Scientific Research Network of Historical Demography (FWO Flanders, http://www.historicaldemography.be) and the International Institute of Social History Amsterdam (IISH, http:// socialhistory.org/). Manuscripts are reviewed by the editors, members of the editorial and scientific boards, and by external reviewers. All journal content is freely available on the internet at http://www.ehps-net.eu/journal.

Editors: Koen Matthijs \& Paul Puschmann

Family and Population Studies

KU Leuven, Belgium

hislives@kuleuven.be

The European Science Foundation (ESF) provides a platform for its Member Organisations to advance science and explore new directions for research at the European level. Established in 1974 as an independent non-governmental organisation, the ESF currently serves 78 Member Organisations across 30 countries. EHPS-Net is an ESF Research Networking Programme.

The European Historical Population Samples Network (EHPS-net) brings together scholars to create a common format for databases containing non-aggregated information on persons, families and households. The aim is to form an integrated and joint interface between many European and non-European databases to stimulate comparative research on the micro-level.

Visit: http://www.ehps-net.eu.
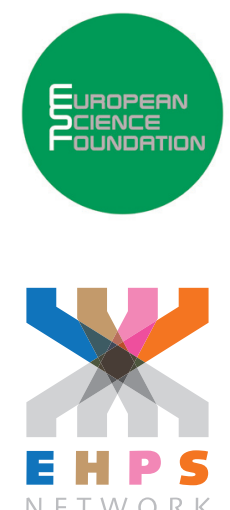


\title{
Environmental Influences on Young Adult Male Height
}

\section{A Comparison of Town and Countryside in the Netherlands, 1815-1900}

\author{
Jan Kok \\ Radboud University Nijmegen \\ Erik Beekink \\ Netherlands Interdisciplinary Demographic Institute, The Hague \\ David Bijsterbosch \\ Radboud University Nijmegen
}

\begin{abstract}
The first phase of industrialization has often been associated with decreasing standards of living for workers, and early industrial towns and cities gained bad reputations. One of the best indicators for living conditions in early life is young adult height, and the literature has often pointed at urbanrural differences in heights to illustrate the initial decrease of living standards due to urbanization and industrialization. But how was urban residence connected to height? Causal mechanisms can include disease environment related to crowdedness, food availability or the nature of urban versus rural work. But perhaps urban-rural differences can simply be attributed to compositional effects, e.g. in cities relatively more poor, illiterate or incomplete families were to be found. Another question is whether urban-rural differences are limited to large cities compared to the rest, or whether we also find differences between towns and villages. In this brief, exploratory paper, we combine two detailed local datasets to provide answers to these questions. We contrast an early industrializing town, with a typical proletarian sub-culture of tile bakers and a significant middle class (Woerden in the province of South-Holland) to an agrarian community (the village of Akersloot and surrounding area in the province of North-Holland). Our dataset allows us to disentangle effects of the family composition, the family's socio-economic status, food prices, and the environment on bodily growth of 1,738 young men. Our results suggest that the specific conditions of urban workers were more important for the physical development of their children than the urban or rural setting itself.
\end{abstract}

Keywords: Urban-rural differences, Anthropometric history, Resource dilution, Holland, 19th century

e-ISSN: $\quad$ 2352-6343

PID article: $\quad$ http://hdl.handle.net/10622/23526343-2017-0010?locatt=view:master

The article can be downloaded from here.

(C) 2017, Jan Kok, Erik Beekink, David Bijsterbosch

This open-access work is licensed under a Creative Commons Attribution 4.0 International License, which permits use, reproduction \& distribution in any medium for non-commercial purposes, provided the original author(s) and source are given credit. See http://creativecommons.org/licenses/ 
Increasingly, heights are being used as an indicator of the 'biological standard of living' or the health of past populations. Social differences in heights reflect differential access to (good) nutrition, differential exposure to diseases, differences in health care, and variation in work load (Bozzoli, Deaton, \& Quintana-Domeque 2009; Silventoinen 2003). Not surprisingly, differences in height between urban and rural dwellers have often been noted and associated with the 'urban penalty', i.e. the bad living and housing conditions in cities prior to the advent of modern sanitary reforms (Ayuda \& Puche-Gil 2014; Floud et al. 2011; Ramon-Muñoz \& Ramon-Muñoz 2017; Steckel 1995). Height differentials between urban and rural dwellers probably increased during early industrialization. This is sometimes used to illustrate the 'early growth paradox' or the decreasing standards of living in a period of growing national incomes (De Jong 2015). To be sure, living conditions in urban places were not always worse than in the countryside. Cities with a considerable middle class and with good access to food might have done as well as the countryside, or even better when the countryside was particularly impoverished, as was the case in large parts of nineteenth-century Spain (Martínez-Carrión \& Moreno-Lázaro 2007; for Lisbon, cf. Reis 2009). Also, in nineteenth-century Eastern Belgium, men in industrializing communities were not always shorter than men in rural localities (Alter, Neven \& Oris 2004). In the last decades of the nineteenth century, the gap in height between urban and rural places became smaller (Steckel 1995), and in several places during the twentieth century might even have reversed. An example of such an 'urban premium' in height is contemporary China (Luo et al. 2009).

But what is the 'urban factor' in height, and how does it relate to other causal mechanisms? A child's growth can be hampered - at least temporarily - by heavy drains on its energy, which can be caused by malnutrition, by protracted or repeated diseases, or by heavy work. The proper intake of nutrients (especially proteins) is a crucial determinant of growth (Öberg 2014:23). In the Netherlands, due to its integrated market economy, local crop failures were not as fatal as elsewhere. However, a sizeable part of the laboring population already lived at the subsistence level (De Meere 1982; Verdoorn 1981), and their food intake deteriorated further in the first half of the nineteenth century due to exports and risings prices of dairy products, the Potato crisis of the 1840s, and the effects of the Crimean War on grain imports (Knibbe 2007). The resulting decline in stature occurred in many industrializing countries at the time (Steckel 2009). Diseases draw energy from the body, and reduce its capacity for intake of nutrients and thus impairs growth. Protracted and repeated diseases, such as diarrhoea, can lead to lasting effects on height (Öberg 2014).

Living in urban places in the nineteenth century might have increased the likelihood of impaired growth because of, amongst others, a) the disease environment, b) food availability, and c) working conditions. High population density, together with air and water population, increases the chances of infectious diseases. Also, until the late nineteenth century, poor urban residents were dependent on low quality food. For instance, the poor in Amsterdam could not rely on the quality of the milk brought to the city as it was often adulterated by the vendors (Verdoorn 1981). Working conditions of urban adolescents, especially in factories or workshops, were more likely to be adverse to their growth than for rural boys working outdoors. The 'urban penalty' might have disappeared or even be reversed when working, housing, and sanitary conditions began to improve, when the sale of bread, meat and dairy were subjected to government controls, and when urban residents could benefit from medical care and facilities.

Heights may also reveal social conditions in the family. The socio-economic position of the household during early life affects the growth of children in several ways. Family income is, of course, directly related to food availability, but social position also affects clothing (as fighting the cold also forms a drain on energy), proper care and the effective treatment of diseases (Silventoinen 2003). According to Alter et al. (2004), nineteenth-century differences in the height of children from different socioeconomic groups relate more to income than to exposure to diseases, as the richer groups were not (yet) able to protect themselves from infectious diseases. Furthermore, the feeding and caring for individual children may have differed by their position in the sibling order and may also have been dependent on the family size. Household heads constantly had to make decisions about what to spend their incomes on. Family size has been shown to be inversely correlated to height of children (Hatton \& Martin 2010). The decision-making depends on whether the head is male or female, and also on the relative leverage of husband and wife. Often, the bargaining power of the mother and/or her educational level translates itself in better nutrition and medical care for the children (Horrell \& Oxley 2013; Kuh \& Wadsworth 1989; Song 2008). Cultural preferences for mostly sons have been shown to 
affect differences in height between siblings (Steckel 2009). Finally, children experiencing the loss of a parent at an early age might have been strongly affected by this bereavement.

Obviously, intergenerational transmission of, among others, genetic traits also plays a large role. So far, historical demographers have made only a few attempts to understand the complex set of factors that cause height variation (Alter \& Oris 2008; Öberg 2014). In this paper, we cannot go into the genetic factors involved in height, but we can try to disentangle the two important groups of environmental influences: the (urban or rural) locality and the household (in terms of resources and resource allocation). One of the first tasks will be to find out whether there is a true independent urban effect, or whether aggregated urban-rural differences were simply caused by compositional effects; e.g. because there were more poor households in cities (Nicholas \& Steckel 1991).

In historical anthropometrics, the combination of detailed household information and children's growth is very rare. Recently, there is more attention to the behavioral responses of urban households during early industrialization (Puschmann \& Solli 2014), but the sources (census and population registers) are hardly ever linked to medical examinations. Conversely, the conscripts or prisoners found in records indicating their heights are hardly ever traced back to their early life conditions (Hatton 2017). The high-quality data we require are available for the municipalities of Akersloot and Woerden in the nineteenth century. Akersloot is a rural community in the province of North-Holland, and Woerden is an early industrializing town in the province of South-Holland. Clearly, we cannot expect its social conditions to be representative of larger urban communities like Amsterdam, but Woerden does have some characteristics that make for an interesting comparison.

In the next section we will introduce these localities in more detail, and discuss the databases on which we build our analysis. In the first analytical section, we study the impact of socio-economic factors in both localities, such as occupational group, literacy and price fluctuations. Then, we use subsamples for which we have detailed household information. With these more limited samples, we can study the effects of household composition and childhood deprivation, which we measure through rank order, family size, the early death of the mother and growing up in a family with high levels of infant and child mortality. Adding interactions to the models tell us to what extent factors played out differently in urban or rural contexts. Finally, we summarize the results in a concluding section.

\section{THE MUNICIPALITIES OF AKERSLOOT AND WOERDEN}

The municipalities of Akersloot and Woerden are located in the western parts of the Netherlands (see Figure 1). The entire region was characterized by relatively high population density, good transport infrastructure and commercialized agriculture, focusing on dairy production.

The municipality of Akersloot in the province of North-Holland has a rather unique location, as it surrounds a large lake. Thus, it consists of rather loosely connected parts, which, in fact, makes it more or less typical of the 'open' landscape of North-Holland (Damsma \& Kok 2005). In 1849, population density was 42 inhabitants per square kilometer. The largest center was the actual village of Akersloot with two-thirds of all inhabitants. The municipality was completely dominated by farming, and even shopkeepers and workers had some livestock. In 1840, the mayor even wondered whether 'The cattle survey should include destitute people who keep one or two sheep' (Municipal Archives, minutes of the Council, 1840, quoted in Damsma \& Kok 2005, pp. 289). Although dairy farming was predominant, after 1880 bulb farming became increasingly important.

In 1809, Akersloot had 786 inhabitants, a number that would increase to 1,635 by 1889 . Roman Catholics formed around $40 \%$ of the inhabitants, and almost everyone else was Dutch-Reformed. In this municipality, mortality levels were rather moderate, and Akersloot was spared from outbreaks of epidemic diseases. For instance, the cholera epidemic of 1840 only claimed two victims, whereas the coastal village of Zandvoort, about thirty kilometers away, lost 150 out of 1,136 inhabitants (Jacobi 1867). However, malaria was endemic in this region. 


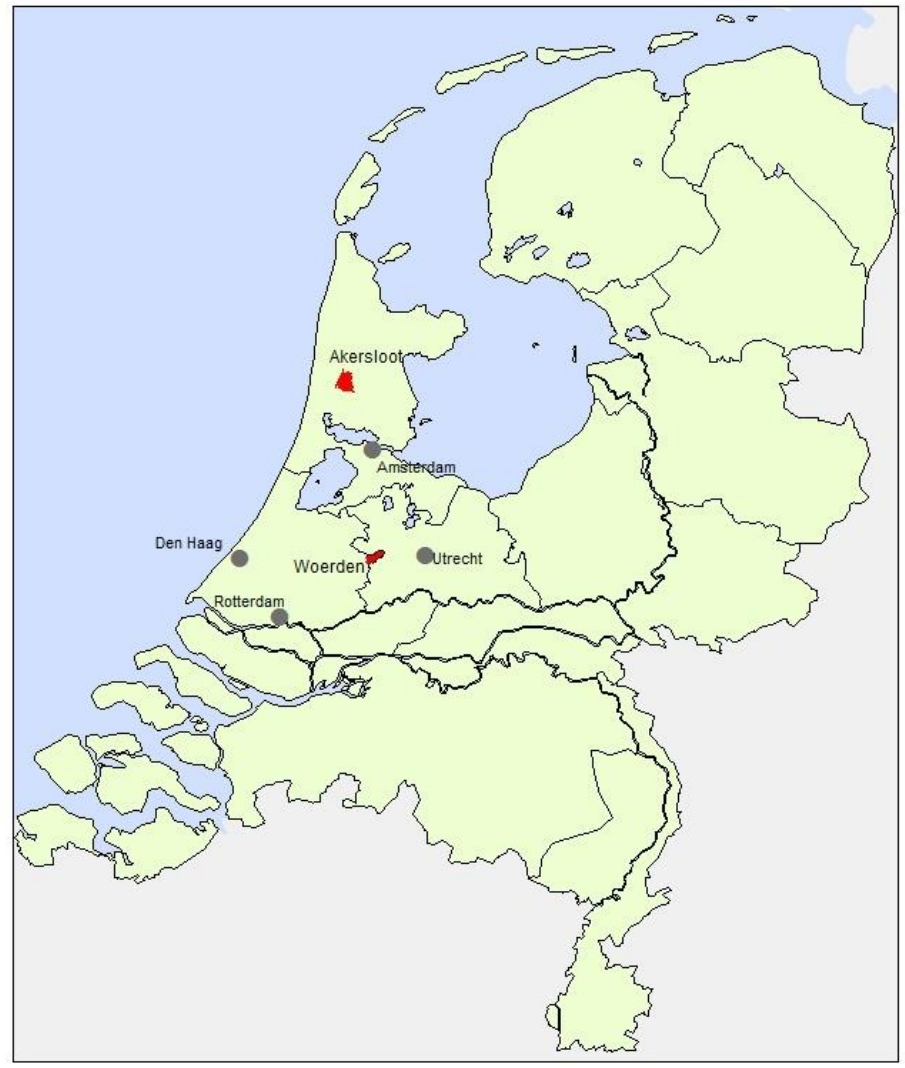

The town of Woerden boasted ancient city rights. It had a central function for the surrounding area and hosted a market, a hospital, a prison as well as military barracks. Furthermore, the town experienced early industrialization in the form of brick and tile works. In the beginning of the nineteenth century, it had a population of around 2,600 inhabitants; by 1840 this number had increased to 4,000. Population density in 1849 was 338, thus eight times as high as Akersloot. The growth of the population during the first half of the nineteenth century was largely caused by net migration. In fact, without a strong in-migration the population would have, at least during the first quarter of the nineteenth century, decreased (Van der Laarse 1989). This positive migration flow was mainly caused by industrial growth. In the second half of the nineteenth century this growth slowed down; in 1889, the place counted 4,674 inhabitants.

In the early 1830s and in the late 1840s Woerden experienced mortality crises with peaks around 1832 and 1848 as a result of intestinal and infectious diseases such as malaria, smallpox and cholera asiatica. The town was situated in the center of a region that was hit hardest by the cholera epidemics (Van der Laarse 1989).

A closer look at the map of Woerden municipality (Figure 2) shows that it can be divided in three separate sections: the inner city in which the middle class and the elite lived, the agricultural section and a third, separate, section with brick and tile factories and small houses for laborers. The brick and tile works and related industries formed a sub-community within the municipality, with even its own dialect. Life at the Pannebakkerijen (tile works) was hard; the literature gives the impression of Dickensian social circumstances (Van der Laarse 1989; Janssen 1987). The brick and tile workers were housed in small factory houses situated between big ovens and racks from stones and tiles. This led to very bad hygienic conditions, an important cause of the diseases mentioned earlier (Van der Laarse 1989). In this industry, the whole family took part in the process of producing bricks or tiles; thus female and child labor was important. The brick and tile industry was a seasonal business. The workers earned their income during the production season that ran from early April to early October - at least if the weather did not make it impossible to work, in which case nothing was earned. During the winter months the workers were without income. They were mostly dependent on aid from the churches or municipal poor relief unless their bosses paid them the so-called 'winter money'; a loan with the 
purpose to bind the workers to the company for the next season. Brick-making was contract work; the workers were hired every year (in July or August) again for the next season by the manufacturers (Stadhouders 2015).

\section{Figure 2 Map of Woerden municipality}

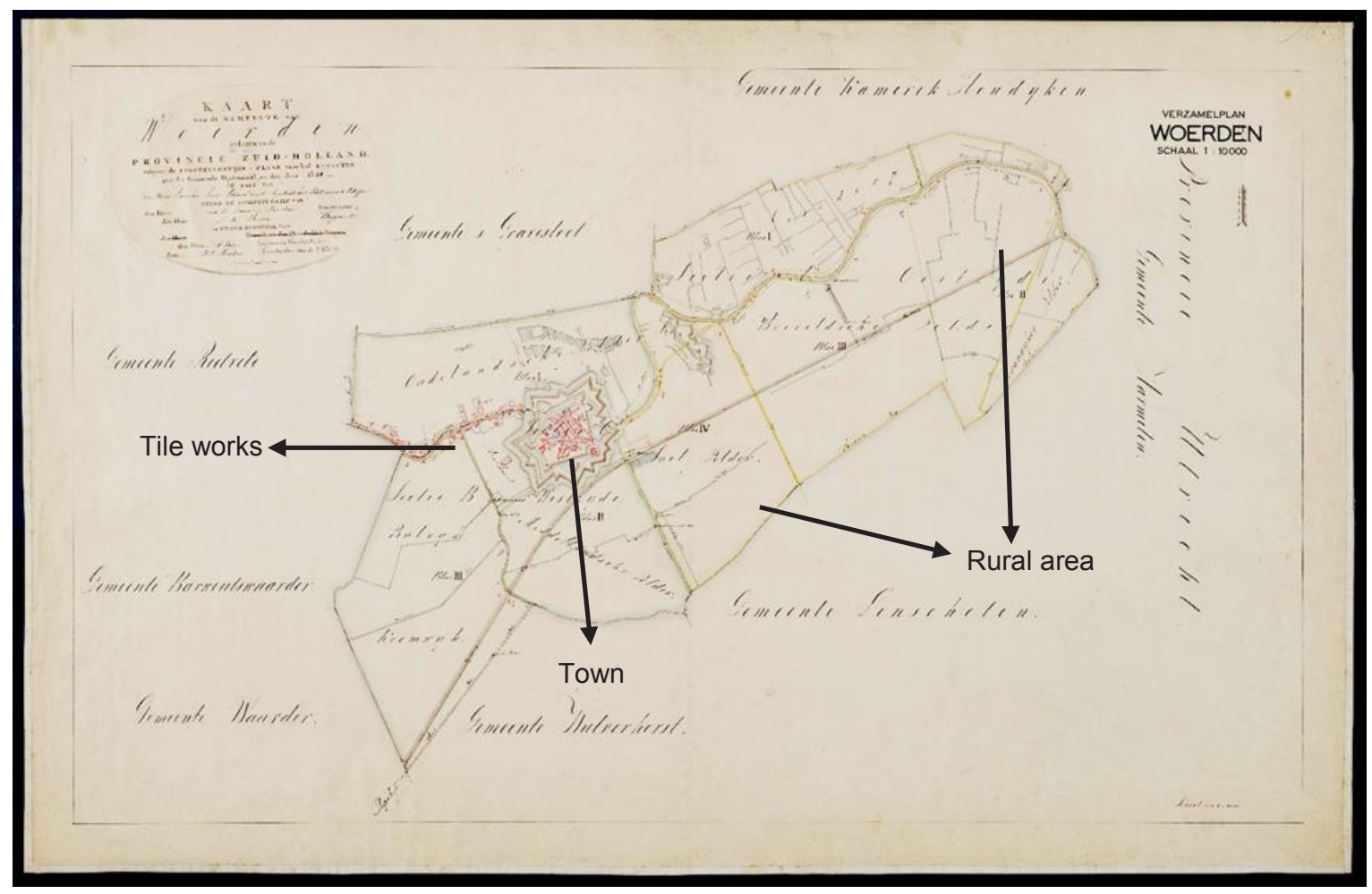

Note: Cadastral map 1828, Nationaal Archief, Den Haag, Minuutplans en Verzamelplans van het Kadaster Zuid-Holland, District 's-Gravenhage, nummer toegang 4.KADOR-G, inventarisnummer 662.

Although the number of laborers increased in the first half of the nineteenth century, the proletarian part of the population of Woerden was still smaller than in many Dutch cities. There was a considerable middle class, partially due to the military barracks and the prison, which attracted all kinds of additional labor. Next to this, as noted, Woerden had a central function for the surrounding area, and counted notaries, medical doctors, civil servants, factory owners among its inhabitants. Woerden municipality also consisted of a sizeable rural area (see Figure 2), which means that the occupational structure included quite a lot of farmers. In the course of the nineteenth century, these farmers concentrated on cheese making (Van Drie \& Van Es 1985). In fact, the area was among one of the last in The Netherlands to abandon cheese making at home, a craft in which the farmer's wife and daughters performed crucial tasks (Verstoep 1989).

Around 1840, about one-third of the Woerden population was Roman Catholic, and almost $60 \%$ of the inhabitants adhered to the Dutch Reformed Church. Smaller Protestant groups as well as Jews made up the remainder (Beekink, Van Poppel \& Liefbroer 2002).

This study is based on conscription records, as well as on data derived from civil records and population registers. Conscription for military service was introduced during the French Period. In each year, all male residents who turned 19 years of age that year were registered, as well as those who had been exempted in the preceding year (Koerhuis \& Van Mulken 1986). The quality and the usefulness of the military registers are discussed in many publications (Drukker, Brinkman \& Van Meerten 1991; Mandemakers \& Van Zanden 1990; Oppers 1963). Brinkman, Drukker and Stuurop (1989) concluded 
that there was no indication that the higher classes of the society were systematically underrepresented in the registers. The accuracy of the height measurements is difficult to ascertain. However, as with tax registration, one might assume that for both parties it was important that the registration, and in particular the height measurement, was done well. After all, the height determined if one, in principle, was eligible for military service. Registers show that sometimes if people were only a few centimeters too small, they were rejected that year, but were measured again the next year. Interesting in this context is that already in 1863 this source was used for an official report about the influence of child labor on, for example, the height of people (De Vries Robbé 1872). This suggests that at the time these military registers were valued as a reliable source.

In the Woerden case, we have started with the conscripts measured at age $19(\mathrm{~N}=1,207)$. We then derived their socio-economic and family characteristics from the linked birth, death and marriage certificates (available from 1811 onwards), as well as from the digitized ten-yearly censuses starting in 1829 (Beekink \& Kok 2017; Beekink et al. 2002). For conscripts born outside Woerden, information on early life conditions is mostly lacking. In Akersloot, a different procedure was followed. Here, the analysis is based on a detailed dataset of two generations followed on a day-by-day basis using the population registers. Akersloot municipality was exceptional in that it has kept a dynamic administration of the population already from 1830 onwards, whereas most other municipalities started their registers in 1850 (Woerden was also early, with registers starting in 1840). The Akersloot population registers recorded marriages, births, migrations and death of individuals, as well as their occupation and religion. From the period 1830-1879, all 298 first marriages in which the husbands actually lived in Akersloot were included if it was the first marriage for both partners. Seventeen couples left the parish soon after the marriage and could not be traced in nearby villages. The remaining 281 couples were followed until the death of the last remaining spouse, regardless of where they happened to live (Van Bavel \& Kok 2009). In addition, all their children (no less than 1,718, including those from second marriages) were followed in all their migratory movements. The dataset is archived as part of the Historical Sample of the Netherlands as Release GBW2. The men, as well as their sons, were traced in the militia records, provided they were born before 1880 . Thus, our dataset includes 170 men in the first generation, 328 in the second, and 68 in the third ( $N=566$ in total).

Thus, both in Woerden and Akersloot, the data is strongly clustered in families, as many brothers, as well as fathers, are included. In our multivariate analyses, we need to account for the nested nature of the data. A first inspection of the median heights (Figure 3) by five-yearly birth cohorts in both municipalities is shown below. In rural Akersloot, boys born between 1815-1824 were shorter than in Woerden. But we see a clear improvement in the village in the younger cohorts.

Figure 3 Median heights of conscripts by birth period, 1800-1879, municipalities of Woerden and Akersloot

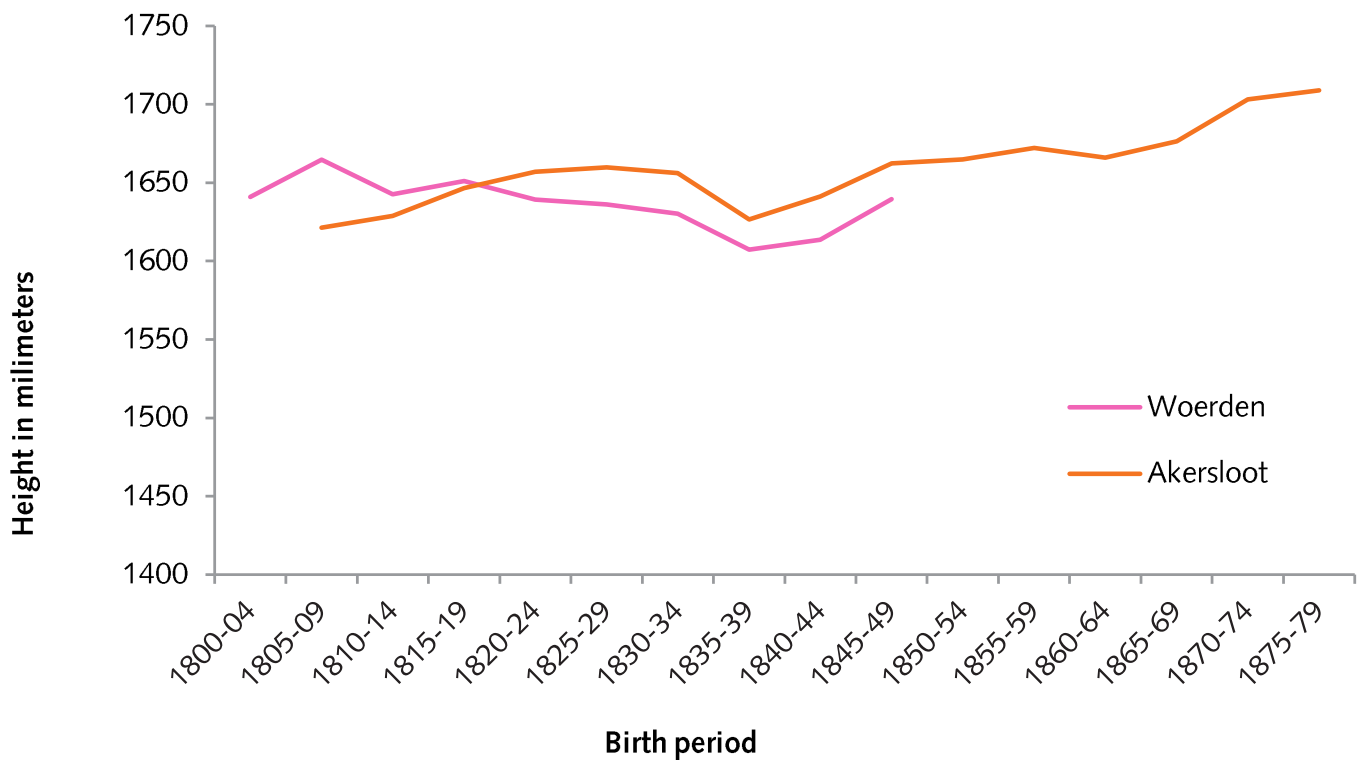

Source: Militieregisters Akersloot 1817-1899, Alkmaar, Regionaal archief Alkmaar, Gemeente Akersloot 1817-1930, Woerden, Archief Nationale militie 1814 - 1871. 
As we also have data from the second half of the nineteenth century for Akersloot, we can observe the overall increase found across the Netherlands (Knibbe 2007). Unfortunately, we cannot contrast this to developments in Woerden. The differences in the periods of observation imply that we also have to account for period effects in comparing both localities. Changes in the procedures could also influence our comparison of these localities. Before 1861, conscripts were measured when they were on average 18 3/4 years of age, and after 1861 a year later, thus at 19 3/4 year (Koerhuis \& Van Mulken 1986). Thus, conscripts born after about 1841 or 1842 were almost by definition taller than boys born earlier, as they had a year longer to continue growing. Based upon military records, Oppers (1963) studied in detail the growth between the age of 19 and 25 years. He concluded that catch-up growth was a normal phenomenon, but it diminished in the course of the nineteenth century (Oppers 1963). Beekink and Kok (2017) calculated a median catch-up growth of five centimeters for Woerden boys between age 19 and age 25 .

As we are interested in rural versus urban conditions, it may be more revealing to remove the rural parts of Woerden municipality (see Figure 2), which is possible because the addresses of the recruits are known. As the rural part of Woerden is rather similar to Akersloot, it makes sense to join both regions together. In Figure 4, we gain a clearer picture of height developments in town (Woerden proper) and countryside (Akersloot, the polder areas surrounding the Alkmaardermeer, and polder areas of Woerden).

Figure 4 Median heights of conscripts by birth period, 1800-1879, countryside of Woerden and Akersloot and town of Woerden

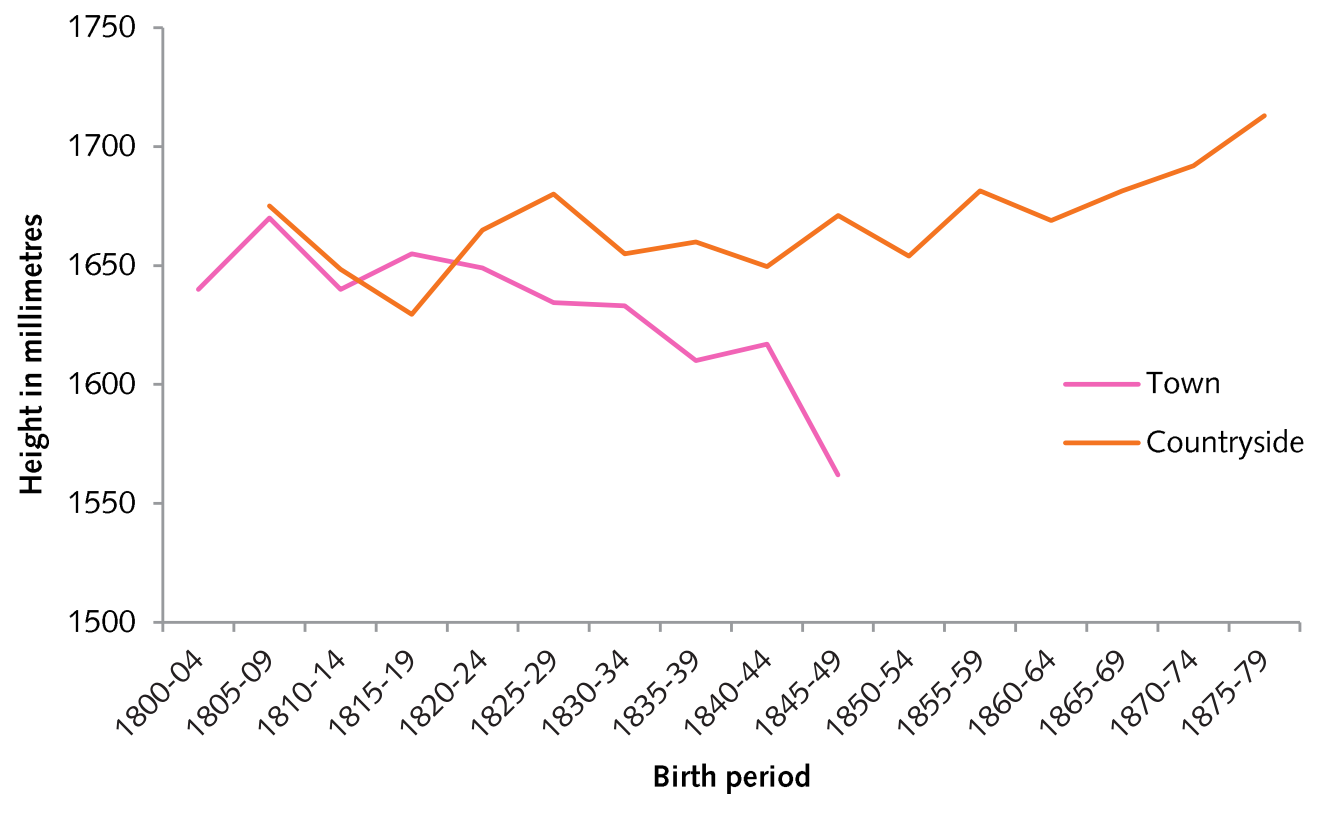

Source: Militieregisters Akersloot 1817-1899, Alkmaar, Regionaal archief Alkmaar, Gemeente Akersloot 1817-1930, Woerden: Archief Nationale militie 1814 - 1871.

The figure shows that the relatively positive results of Woerden have to be attributed to its farming population in the polder parts of the municipalities. The inner city and the industrial quarter did worse than the countryside, especially for boys born after 1820 . The gap seems to increase at least until the birth cohort 1845-1849, but for this last period we only have two observations.

How much of the differences between our two locations can be ascribed to compositional effects? Let us first inspect height differences by occupational categories, that is we look at the occupations of the fathers. We compare only boys born in the same period (1804-1849) (Figure 5). 
Figure 5 Median height in millimeters of recruits (19-20 years old) by socio-economic class of their fathers, Woerden and Akersloot (men born 1804-1849).

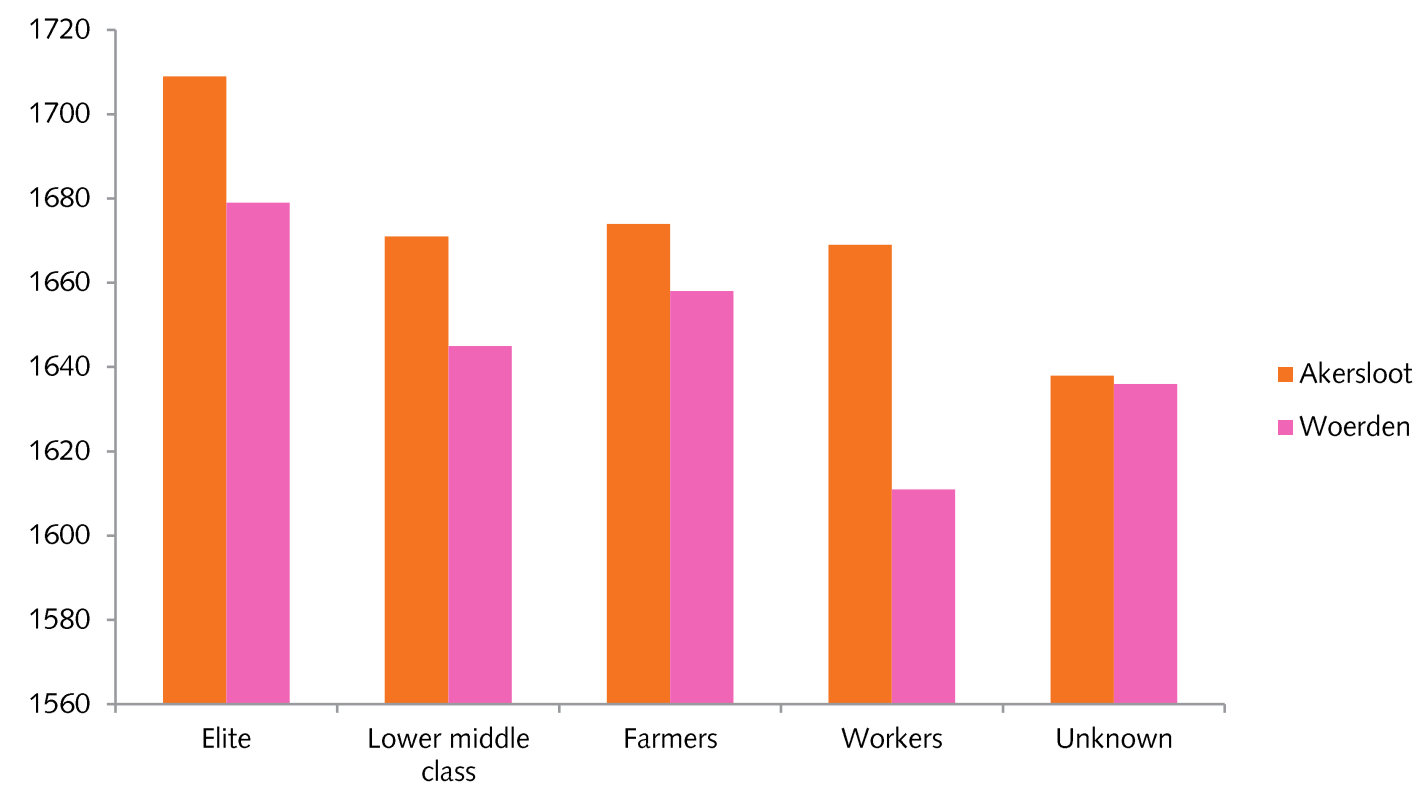

Source: Akersloot: Historical Sample of the Netherlands,Release GBW2; Woerden: Archief Nationale militie $1814-1871$

Our results, although based on small absolute numbers, suggest that - as elsewhere (Steckel 1995) - boys from elite families were considerably taller than boys from other families. In Akersloot, the differences between sons of farmers, lower middle class (shopkeepers, lower supervisors, etc.) and workers were limited, but sons of workers in Woerden were much shorter than others. Interestingly, we do see that in all occupational categories Akersloot boys were taller than their Woerden counterparts. In other words, the differences between the municipalities is not just a compositional effect in terms of socio-economic status. But still, however, the aggregate differences can be affected by the relative presence of tall or short groups. In Akersloot, only two fathers (a mere $0.3 \%$ ) could be considered elite, versus $3 \%$ of the fathers in Woerden. More important for the aggregates of course is the presence of farmers ( 43.3 versus $10.2 \%$ ). On the other hand, fathers whose occupation was unknown - and who tended to have shorter sons - were more numerous in Woerden (21.0 versus $14.7 \%$ in Akersloot).

\section{MODELLING YOUNG ADULT HEIGHT}

To disentangle the effects of local environment and household on height, while controlling for period, we need to perform a multiple regression analysis. This needs to be a multilevel analysis as we have included several brothers in our study. Not taking into account the clustered nature of the data would lead to overestimation of the covariance terms. Brothers may be of similar height, not because they share a similar (observed) socio-economic background, but because of other, unobserved factors, such as genes. We have used the Stata command xtreg, and cluster observations by mother (Rabe-Hesketh \& Skrondal 2005). We begin with the full sample, and afterwards proceed to subsamples for which we have more detailed information on the household situation in early life.

In Table 1, the results of the first exploration are presented. Model 1 simply looks at the effect of the local context: how tall did boys growing up in the town (of Woerden) become compared to boys growing up in the rural parts of Woerden and Akersloot? We also add a 'municipality effect' to see whether a municipality effect remains once we control for the rural-urban differences. Figure 5 seems to suggest that a municipality difference existed, as, for instance, farmers in Woerden were shorter than those in Akersloot. A municipality effect may point at, for instance, differences in social policy. Poor relief was organized locally, and the amount and type of relief given to the poor could differ 
significantly across communities (Van Leeuwen 2003). Model 1, however, makes clear that while growing up in a town led to significantly lower heights at age 19 (2.3 centimeters), the small negative effect of growing up in Woerden municipality compared to Akersloot was not significant.

Of course, we have more observations on Akersloot in a more favorable period. It is therefore imperative that we control for period effects. In Model 2, we add birth year, but also a square term for birth year to capture non-linear aspects of the trend in heights. What are favorable and what are unfavorable periods? Ideally, we would like to evaluate the effects of epidemic diseases, of changes in poor relief, and changes in real wages. In this article, we restrict our analysis to crises in food availability. We use a composite and weighted index of food prices (Van Zanden \& Van Riel 2004), and define a crisis as a higher than ten percent increase in food prices relative to the average of 1800-1913, occurring during the period when the recruit was between 13 and 15 years of age, a period during which most boys experienced a growth spurt (Oppers 1963). Model 2 shows that period effects are indeed highly important, and the overall fit of the model improves. The effects of birth year and birth year squared indicate a trend with a slight U-shape. High food prices during early adolescence had the expected negative effect on height at age 19.

Our next model (Model 3 ) includes the socio-economic class of the parental households of the military conscript. To create socio-professional categories, we used father's occupation as noted in father's marriage certificate (Akersloot) or the recruit's birth certificate (Woerden) as a prime indicator. We have used the well-known HISCO coding and the HISCLASS (Van Leeuwen \& Maas 2011) classification to create broad categories. Again, this turns out to be a major improvement of the regression model. When compared to boys from the lower middle class (shopkeepers, artisans etc.), boys from an elite background were much taller, by almost three centimeters. On the other hand, sons of unskilled workers were almost three centimeters shorter. Interestingly, sons of farmers were not significantly taller than boys from the lower middle class.

In Model 4 we add several other indicators of the social position of the family. The education of the mother is found to be an import predictor of a child's health (Steckel 2009), and although we do not have detailed information on the schooling of the parents, we include the ability to sign the marriage certificate as a proxy for literacy, and thereby a proxy for level of education. Mothers, as well as father's literacy might offer some insight into the family's access to and receptivity for information on health care practices. Also, religion may offer a clue to the family's socio-cultural situation. Although we do not know much about religious differences in child-rearing practices, it has been shown that denomination mattered for many aspects of demographic behavior, such as infant mortality (Kok 2017). Again, the fit of the model improves when we add these variables to the model. As suggested by the literature, illiteracy of the mother was associated with shorter stature. And Jewish boys were much shorter than Protestant (and Roman Catholic) boys. Jewish infants had, in general, better survival chances than their Christian counterparts (Kok 2017), so it is not likely that, e.g., poor hygiene and illnesses are the cause of this outcome. The shorter stature might be related to the problems Jews often faced in acquiring kosher meat (Tassenaar \& Karel 2016).

Do economic crises, and do social conditions play out differently in an urban setting than in a rural setting? To answer this question, we ran models including interaction terms. We expected that economic crises (rising food prices) hit the urban population harder than the rural one, but the interaction coefficient was not significant. Indeed, in his social history of Woerden, Van der Laarse (1989) already noted that the economic crises of the first half of the nineteenth century did not seem to strongly affect Woerden society. We also tested an interaction term for town and workers, which did produce slightly significant results (Model 5). In the model (with only a marginal better fit than Model 3) the main effect of town versus countryside disappears, as well as the main effect of the 'workers' variable, and thus suggests that both the effects of living in a town, and of being the son of a worker, were strongly influenced by the specific conditions of workers in the town. This leads us, of course, to the specific conditions of the Woerden brick makers and their children. In the Woerden brickmaking industry, child labor was common. Child labor, especially when it concerns physically demanding work, is another drain on the energy needed for growth. The adverse impact of labor on height was already noted in the mid-nineteenth century, e.g. by the medical doctor Coronel who in 1862 observed a difference in stature of no less than 11.5 centimeters between young factory workers and fishermen's sons (Tassenaar 2000). 
Table 1 Random effects generalized least squares regression models of local and household effects on stature (measured in centimeters), Akersloot (men born 1804-1879) and Woerden (men born 1795-1849).

\begin{tabular}{|c|c|c|c|c|c|}
\hline & Model 1 & Model 2 & Model 3 & Model 4 & Model 5 \\
\hline Town (countryside=ref.) & $-2.383 * *$ & $-2.239 * *$ & $-1.811+$ & $-1.826+$ & -0.110 \\
\hline Woerden (Akersloot=ref.) & -1.066 & 0.261 & -0.182 & 0.179 & -0.301 \\
\hline Birth year & & $-0.253 * * *$ & $-0.247 * * *$ & $-0.235^{* * *}$ & $-0.241 * * *$ \\
\hline Birth year ${ }^{2}$ & & $0.003 * * *$ & $0.003 * * *$ & $0.003 * * *$ & $0.003 * * *$ \\
\hline Food price fluctuations & & $-1.537 * * *$ & $-1.526^{* * *}$ & $-1.499 * * *$ & $-0.503 * * *$ \\
\hline \multicolumn{6}{|l|}{ Lower middle class (ref.) } \\
\hline Elite \& higher middle class & & & $2.959 *$ & $3.503 *$ & $2.858^{*}$ \\
\hline Farmers & & & -0.371 & -3.386 & 0.187 \\
\hline Workers & & & $-2.791 * * *$ & $-2.523 * * *$ & -1.216 \\
\hline Unknown & & & $-1.760 * *$ & $-1.450^{*}$ & $-1.718^{* *}$ \\
\hline $\begin{array}{l}\text { Mother illiterate (liter- } \\
\text { ate=ref.) }\end{array}$ & & & & $-1.853^{*}$ & \\
\hline Literacy mother unknown & & & & -0.647 & \\
\hline Father illiterate (literate=ref.) & & & & -0.363 & \\
\hline Literacy father unknown & & & & -0.464 & \\
\hline $\begin{array}{l}\text { Roman Catholic (Protes- } \\
\text { tant=ref.) }\end{array}$ & & & & -0.111 & \\
\hline Jewish & & & & $-5.899 *$ & \\
\hline Religion unknown & & & & 0.493 & \\
\hline Interaction town* workers & & & & & $-2.092 \dagger$ \\
\hline Model chi ${ }^{2}$ & $48.52 * * *$ & $101.35 * * *$ & $141.39 * * *$ & $156.45^{* * *}$ & $145.39 * * *$ \\
\hline Within $r^{2}$ & 0.00 & 0.02 & 0.02 & 0.02 & 0.02 \\
\hline Between $r^{2}$ & 0.04 & 0.07 & 0.10 & 0.12 & 0.11 \\
\hline Overall $r^{2}$ & 0.03 & 0.07 & 0.09 & 0.10 & 0.10 \\
\hline Rho & 0.46 & 0.45 & 0.44 & 0.43 & 0.44 \\
\hline $\mathrm{N}$ observations & 1,738 & 1,738 & 1,738 & 1,738 & 1,738 \\
\hline $\mathrm{N}$ groups & 1,080 & 1,080 & 1,080 & 1,080 & 1,080 \\
\hline
\end{tabular}

Note: ** $p<.001 ;{ }^{* *} p<.01 ;{ }^{*} p<0.05 ;+p<0.1$

Our next series of models (see table 2) deal with family composition, and in particular the question how resource allocation within households could affect height. Does family size have such a strong effect that children with a large number of siblings are shorter than children from smaller families? Recently, several studies have confirmed the importance of 'resource dilution' for stature, although the association between family size and stature may be caused by other, unobserved explanatory factors (Öberg 2017). Another factor is rank order. Children may have been treated differently, or experienced different conditions depending on their position in the sibling order. The problem of finding an independent effect of rank order is its strong correlation with family size. This is why several scholars work with an index of rank order, which adjusts for family size. The index has been created by Booth and Kee (2009), and has recently been used by Öberg (2014) and Ramon-Muñoz \& RamonMuñoz (2017). The index is defined as birth order/(number of children+1)/2). In this way, a single child receives a score of 1 , the first out of two children gets 0.66 , the second gets 1.33 , and so on. Thus, children born first in a large family receive low scores, and children born last in such families receive high scores. The index is not correlated to family size $(-.02, \mathrm{~N}=754)$. This index has the benefit of taking account of the family cycle, or the different conditions in different stages of each family's development. Children who were growing up in a period when the parents were taking care of many small children probably did worse than children who could benefit from the undivided attention by the parents (first and only children) or who could benefit from the help and income brought in by older siblings (last children). Because of this non-linear effect, we include a square term, and also create a 
dummy variable for only children (cf. Öberg 2014, pp. 117; Hermanussen, Hermanussen \& Burmeister 1988; Wells \& Stock 2011). Model 1 in Table 2 shows the main effects of birth order and family, after controlling for the most important factors established in Table 1: town, birth period, food price effects, and socio-economic status measured through occupation of the father. Family size has the expected negative effect, but is not statistically significant, which we already established in an earlier analysis of the Woerden data (Beekink \& Kok 2017). However, the birth order index has the expected non-linear effect: children with a low as well as a high parity did better than children in the middle. The sign for only children is (as expected) positive, but their number is far too small $(\mathrm{N}=6)$ to reach firm conclusions.

Table 2 Random effects generalized least squares regression models of locality, household socio-economic status and family composition effects on stature (measured in centimeters), Akersloot (men born 1804-1879) and Woerden (men born 1795-1849).

\begin{tabular}{|l|l|l|l|}
\hline & Model 1 & Model 2 & Model 3 \\
\hline Town (countryside=ref.) & $-3.464 \dagger$ & $-3.342+$ & $-8.108^{* *}$ \\
\hline Woerden (Akersloot=ref.) & 0.903 & 0.127 & 0.459 \\
\hline Birth year & $-0.377^{* *}$ & $-0.398^{* *}$ & $-0.395^{* *}$ \\
\hline Birth year ${ }^{2}$ & $0.004^{* * *}$ & $0.004^{* * *}$ & $0.004^{* * *}$ \\
\hline Food price fluctuations & $-1.257 \dagger$ & $-1.236+$ & $-1.269+$ \\
\hline Lower middle class (ref.) & & & \\
\hline Elite\&higher middle class & 3.480 & 3.439 & 3.343 \\
\hline Farmers & 0.612 & 0.798 & 0.938 \\
\hline Workers & $-2.124^{* *}$ & 1.335 & $-2.114^{* *}$ \\
\hline Unknown & 0.769 & 0.964 & 0.805 \\
\hline Indexed rank order & -2.946 & -2.868 & -2.811 \\
\hline Indexed rank order ${ }^{2}$ & $2.369^{*}$ & $2.315^{*}$ & $2.290^{*}$ \\
\hline Only child & 0.237 & -0.220 & -1.399 \\
\hline Family size & -0.154 & 0.013 & $-0.410^{* *}$ \\
\hline Interaction family size* workers $^{*}$ & & $-0.445^{*}$ & \\
\hline Interaction family size*town & & & $0.598^{* *}$ \\
\hline Model chi ${ }^{2}$ & $118.70^{* * *}$ & $124.89^{* * *}$ & $127.93^{* * *}$ \\
\hline Within $\mathrm{r}^{2}$ & 0.05 & 0.05 & 0.05 \\
\hline Between $\mathrm{r}^{2}$ & 0.21 & 0.21 & 0.22 \\
\hline Overall $\mathrm{r}^{2}$ & 0.16 & 0.16 & 0.17 \\
\hline Rho & 0.44 & 0.43 & 0.44 \\
\hline $\mathrm{N}$ observations & 754 & 754 & 754 \\
\hline $\mathrm{N}$ groups & 407 & 407 & 407 \\
\hline & & & \\
\hline & & & \\
\hline
\end{tabular}

*** $p<.001 ;{ }^{*} p<.01 ;{ }^{*} p<0.05 ;+p<0.1$

Next, we add interactions, to see whether resource dilution and allocation mechanisms operate differently in specific local or social contexts (Öberg 2017). The interactions of birth order index (and birth order index squared) and town as well as working class did not produce significant results (not shown). Other interactions do produce some puzzling outcomes. The interaction of family size with the working class (Model 2) suggests that resource dilution due to a large family seems to be a problem specifically for workers. Surprisingly, children from large families in town (Model 3) were doing quite well. If we include this interaction effect, the negative effects of town and family size become stronger and more significant. Resource dilution seems to have a much stronger negative impact on stature in the countryside than in the town. So far, we cannot explain this outcome.

Finally, we turn to an analysis of what we call 'bereavement effects'. Children experiencing the loss of a parent at an early age will be more strongly affected by this than children who were adolescents and who might not even live at home. Thus, we created a variable indicating whether the mother died within six years after the recruit was born. We also try to measure the quality of parental care and 
the general conditions in terms of health by looking at the mortality history of the family. In several studies, it has been noted that infant and child mortality tend to cluster in specific families, even after controlling for socio-economic status and other factors usually held responsible for infant and child deaths (Das Gupta 1990; Edvinsson, Brändström, Rogers \& Broström 2005; Vandezande 2012). For instance, the Akersloot family 'Bakker' only had five surviving children out of seventeen births. As yet, we do not know what factors explain this 'death clustering', but possible candidates are genetic factors and 'bad parenting'. We assume that children surviving youth in such 'high risk families' were marked by being shorter than children growing up in 'normal' families. We define high risk families based upon infant and child mortality rates within the family, adjusted for the number of children born (Edvinsson et al. 2005).

Model 1 in Table 3, indicates that after controlling for the main effects, neither the death of the mother, nor high mortality in the family significantly affected height, although the signs are in the expected direction. Perhaps a large sample size would have yielded significant results. Also, most of the interactions with the town and working-class variables are not significant. The only remarkable result is that being born in a 'high risk' family actually had a positive effect on height in town - but again, this can also be read as a negative effect only operating in the countryside. Why would the environment make such a difference? Perhaps death clustering in families signified something different in rural areas than in urban areas; possibly in the first it was a better indicator of bad parenting. In the town of Woerden, death clustering may have been caused by epidemic diseases, and may have struck families much more randomly than in Akersloot.

Table 3 Random effects generalized least squares regression models of locality, household socio-economic status and family bereavement effects on stature (measured in centimeters), Akersloot (men born 1804-1879) and Woerden (men born 1795-1849).

\begin{tabular}{|l|l|l|}
\hline & Model 1 & Model 2 \\
\hline Town (countryside=ref.) & $-4.680^{*}$ & $-7.003^{* *}$ \\
\hline Woerden (Akersloot=ref.) & 1.185 & 2.313 \\
\hline Birth year & $-0.256+$ & $-0.270+$ \\
\hline Birth year ${ }^{*}$ & $0.003^{*}$ & $0.003^{*}$ \\
\hline Food price fluctuations & $-1.734^{*}$ & $-1.724^{*}$ \\
\hline Lower middle class (ref.) & & \\
\hline Elite\&higher middle class & 3.034 & 2.740 \\
\hline Farmers & -0.159 & 0.248 \\
\hline Workers & $-2.233^{*}$ & $-2.238^{* *}$ \\
\hline Unknown & 0.774 & -0.578 \\
\hline High risk family & -1.171 & $-3.032^{* *}$ \\
\hline Mother died early & -1.405 & -1.239 \\
\hline Interaction highrisk*town & & $3.976^{*}$ \\
\hline & & \\
\hline & & - \\
\hline Model chi ${ }^{2}$ & $82.53^{* * *}$ & $89.67^{* * *}$ \\
\hline Within $r^{2}$ & 0.05 & 0.05 \\
\hline Between $r^{2}$ & 0.18 & 0.19 \\
\hline Overall $r^{2}$ & 0.15 & 0.15 \\
\hline Rho & 0.44 & 0.44 \\
\hline N observations & 626 & 626 \\
\hline N groups & & 330 \\
\hline & & \\
\hline
\end{tabular}

${ }^{*}{ }^{*} p<.001 ;{ }^{*} p<.01 ;{ }^{*} p<0.05 ;+p<0.1$ 
Body height results from the complex interplay of genetic endowment, conditions in uterus, availability of food, occurrence or absence of diseases or stress during early life, and workload during adolescence. In this article, we have sought to unravel part of this nexus of causal factors by looking at the impact of socio-economic factors, period effects and family composition on young adult height in two municipalities. By contrasting the rural and urban parts of these municipalities, we investigated to what extent local conditions played an additional role in growth.

Growing up in a town seemingly had a negative effect on height, and this effect remained after controlling for period, food prices, social class, religion and literacy. However, adding an interaction term told us that the specific conditions of the workers in the town (of Woerden) were of most importance. Many of the unskilled laborers were employed in brick-making factories, which included heavy child labor. Thus, we expect that we have not found an 'urban effect' as such, but simply the outcome of bad early-industrial living and housing conditions. For other factors as well, our findings suggest that interactions can direct us to underlying causal mechanisms, and we suggest they should be replicated in studies with a larger sample size. High mortality in families was associated with shorter stature, but only in rural families, which we believe has to do with the impact of severe epidemics which struck the town of Woerden but not the countryside of Akersloot. We expect that 'death clustering' needs to be interpreted differently in these two contexts. Obviously, this has to be confirmed or rejected in further studies.

Our study has made a limited contribution to understanding urban-rural differences in (male) height. The specificity of both regions serves as a reminder that 'average' urban or rural condition do not exist, and that we always need to be aware of local conditions that may affect the results. The municipality of Akersloot and the polder surrounding Woerden are quite representative of the rather prosperous, commercialized dairy regions of the Western and Northern Netherlands. Relatively good access to nutrition needed for growth probably explains why social class differences in height were not strong in this specific countryside. Other rural areas may not have been so fortunate. Perhaps the relative absence of social class differentials also explains why 'family factors' (such as resource dilution) account for more of the variance in height in the countryside than in the town. Similarly, the town of Woerden does not represent urban living conditions in general. On the one hand, it was a rather small community. On the other hand, it had early industrial living and working conditions lacking in many other small cities, and these were clearly related to height. But there are still many factors we would like to include in a more comprehensive study of environmental conditions conducive to growth: presence of gardens and life stock, the impact of epidemics during early life, the functioning of poor relief, housing conditions, etc. More detailed contextual information, in combination with larger population samples, might reveal more of the interplay between social and local conditions than we were able to show in this analysis.

\section{REFERENCES}

Alter, G., Neven, M. \& Oris, M. (2004). Stature in transition. A micro-level study from nineteenthcentury Belgium. Social Science History 28(2), 231-247.

DOI: $10.1017 /$ S0145553200013146

Alter, G. \& Oris, M. (2008). Effects of inheritance and environment on the heights of brothers in nineteenth-century Belgium. Human Nature, 19(1), 44-55.

DOI: $10.1007 / \mathrm{s} 12110-008-9029-1$

Ayuda, M.-I. \& Puche-Gil, J. (2014). Determinants of height and biological inequality in Mediterranean Spain, 1859-1967. Economics and Human Biology, 15, 101-119.

DOI: 10.1016/j.ehb.2014.07.003

Bavel, J. Van \& Kok, J. (2009). Social control and the intergenerational transmission of age at marriage in rural Holland, 1850-1940. Population-E, 64(2), 343-360. 
Beekink, E. \& Kok, J. (2017). Temporary and lasting effects of childhood deprivation on male stature. Late adolescent stature and catch-up growth in Woerden (The Netherlands) in the first half of the nineteenth century. The History of the Family 22(2-3), 196-213.

DOI: $10.1080 / 1081602 X .2016 .1212722$

Beekink, E., Poppel F. Van \& Liefbroer A. (2002). Parental death and death of the child: Common causes or direct effects? In: R. Derosas \& M. Oris (Eds.), When Dad Died: Individuals and Families Coping with Family Stress in Past Societies (pp. 233-270). Bern: Peter Lang.

Booth, A.L. \& Kee, H.J. (2005). Birth order matters: The effect of family size and birth order on educational attainment, IZA Discussion paper no 1713. Bonn: IZA.

Bozzoli, C., Deaton A. \& Quintana-Domeque, C. (2009). Adult height and childhood disease. Demography, 46(4), 647-669.

DOI: $10.1353 / \mathrm{dem} \cdot 0.0079$

Brinkman, H.J., Drukker, W.J. \& Stuurop, S.J. (1989). The representativeness of the Dutch military registers as a source for quantitative history. Economic and Social History in The Netherlands, 1, 149-170.

Damsma, D. \& Kok, J. (2005). Ingedroogde harten? Partnerkeuze en sociale reproductie van de Noord-Hollandse boerenstand in de negentiende en vroeg-twintigste eeuw. In: J. Kok \& M.H.D. van Leeuwen (Eds.), Genegenheid en gelegenheid: Twee eeuwen partnerkeuze en huwelijk (pp. 285-307). Amsterdam: Aksant Academic Publishers.

Das Gupta, M. (1990). Death clustering, mother's education and the determinants of child mortality in rural Punjab, India. Population Studies, 44(3), 489-505.

DOI: 10.1080/0032472031000144866

De Jong, H.J. (2015). Living Standards in a Modernizing World. A Long-Run Perspective on Material Wellbeing and Human Development. In: W. Glatzer, L. Camfield, V. Moller \& M. Rojas (Eds.), Global Handbook of Quality of Life. Explorations of Well-Being of Nations and Continents (pp. 45-74). Dordrecht: Springer

Drie, R. van \& Es, G. van (1985). Een eeuw kaaskop(p)en: De Woerdense kaasmarkt, 1885-1985. Woerden: Stichts-Hollandse Bijdragen.

Drukker, J.W., Brinkman, H.J. \& Meerten M.A. van (1991). Economische ontwikkeling en de lengte van lotelingen: Afgekeurd voor alle diensten? Economisch- en Sociaal-Historisch Jaarboek, 54, 1-15.

Edvinsson, S., Brändström A., Rogers J. \& Broström G. (2005). High-risk families: The unequal distribution of infant mortality in nineteenth-century Sweden. Population Studies, 59(3), 321-337.

DOI: $10.1080 / 00324720500223344$

Floud, R, Fogel, R.W., Harris, B. \& Hong, S.C. (2011). The changing body. Health, nutrition, and human development in the westerns world since 1700. Cambridge: Cambridge University Press.

Hatton, T.J. (2017). Stature and sibship: historical evidence. The History of the Family, 22:2-3, 175195.

DOI: $10.1080 / 1081602 X .2016 .1143856$

Hatton, T. J., \& Martin, R. M. (2010). Fertility decline and the heights of children in Britain, 18861938. Explorations in Economic History, 47(4), 505-519.

DOI: 10.1016/j.eeh.2010.05.003

Hermanussen, M., Hermanussen B. \& Burmeister J. (1988). The association between birth order and adult stature. Annals of Human Biology, 15, 161-165.

DOI: 10.1080/03014468800009581

Horrell, S., \& Oxley, D. (2013). Bargaining for basics? Inferring decision making in nineteenth-century British households from expenditure, diet, stature, and death. European Review of Economic History, 48, 470-481.

DOI: $10.1093 /$ ereh/het003 
Jacobi, H. (1867). De cholera in Noord-Holland. Nederlands Tijdschrift voor Geneeskunde, 11, 111-129.

Janssen, G.A. (1987). Baksteenfabricage in Nederland: Haar eerste mechanisering met name in het gebied van de Grote Rivieren (ca. 1850-ca. 1920). Zutphen: Walburg Pers.

Knibbe, M.T. (2007). De hoofdelijke beschikbaarheid van voedsel en de levensstandaard in Nederland, 1807-1913. Tijdschrift voor Sociale en Economische Geschiedenis, 4(4), 71-107.

Koerhuis, B. \& Mulken, W. van (1986). De militieregisters 1815-1922. Den Haag: Stichting Archief Publicaties.

Kok, J. (2017). Church affiliation and life course transitions in The Netherlands,1850-1970. Historical Social Research, 42 (2), 59-91.

DOI: $10.12759 / \mathrm{hsr} .42 .2017 .2 .59-91$

Kuh, D. \& Wadsworth, M. (1989). Parental height: Childhood environment and subsequent adult height in a national birth cohort. International Journal of Epidemiology, 18(3), 663-668.

DOI: $10.1093 / \mathrm{ije} / 18.3 .663$

Laarse, R. van der (1989). Bevoogding en bevinding. Heren en kerkvolk in een Hollandse provinciestad, Woerden 1780-1930. Amsterdam: Stichting Hollandsche Historische Reeks.

Leeuwen, M.H.D. van (2003). Kerk, staat en burger. Armenzorg en moderne charitas, 1795-2001. In: T. de Nijs \& E. Beukers (Eds.), Geschiedenis van Holland. Deel IIlb 1795 tot 2000 (pp.435484). Hilversum: Verloren.

Leeuwen, M.H.D. van, \& Maas, I. (2011). HISCLASS: A Historical International Social Class Scheme. Leuven: Leuven University Press.

Luo, Y, Yang, F., Lei, S.-F., Wang, X.-L, Papasian, C.J. \& Deng, H.-W. (2009). Differences of height and body mass index of youths in urban vs rural areas in Hunan province of China, Annals of Human Biology, 36(6), 750-755

Mandemakers, C.A. \& Van Zanden J.L. (1990). Lengte van lotelingen en het nationaal inkomen. Schijnrelaties en misvattingen. Economisch-en Sociaal-historisch jaarboek, 53, 1-23.

Martínez-Carrión, J.-M. \& Moreno-Lázaro, J. (2007). Was there an urban height penalty in Spain, 1840-1913? Economics and Human Biology 5, 144-164.

DOI: 10.1016/j.ehb.2006.09.001

Meere, J. de (1982). Economische ontwikkeling en levensstandaard in Nederland gedurende de eerste helft van de negentiende eeuw: Aspecten en trends. 's-Gravenhage: Martinus Nijhoff.

Nicholas, S. \& Steckel, R.H. (1991). Heights and living standards of English workers during the early years of industrialization, 1770-1815, Journal of Economic History 51(4), 937-957 DOI: $10.1017 /$ S0022050700040171

Öberg, S. (2014). Social Bodies. Family and Community Level Influences on Height and Weight, Southern Sweden 1818-1968 (Doctoral dissertation). Retrieved from Gothenburg Studies in Economic History, (10)

Öberg, S. (2017). Too many is not enough: studying how children are affected by their number of siblings and resource dilution in families. The History of the Family, 22(2-3), 157-174

DOI: $10.1080 / 1081602 X .2017 .1302890$.

Oppers, V.A. (1963). Analyse van de acceleratie van de menselijke lengtegroei door bepaling van het tijdstip van de groeifasen. Amsterdam: University of Amsterdam.

Puschmann, P. \& Solli, A. (2014). Household and family during urbanization and industrialization: Efforts to shed new light on an old debate. The History of the Family 19(1), 1-12.

DOI: 10.1080/1081602X.2013.871570

Rabe-Hesketh, S. \& Skrondal, A. (2005). Multilevel and longitudinal modeling using Stata. Berkeley and London: Stata Press.

Ramon-Muñoz, R. \& Ramon-Muñoz, J.-M. (2017). Sibship size and the biological standard of living in industrial Catalonia, c.1860-c.1920: A case study. The History of the Family, 22 (2-3), 333-363.

DOI: $10.1080 / 1081602 X .2016 .1224727$. 
Reis, J. (2009). 'Urban premium' or 'urban penalty'? The case of Lisbon, 1840-1912, Historia Agraria 47, 69-94.

Silventoinen, K. (2003). Determinants of variation in adult body height. Journal of Biosocial Science, 35(2), 263-285.

DOI: $10.1017 /$ S0021932003002633

Song, L. (2008). In search of gender bias in household resource allocation in rural China. IZA Working Paper, No. 3464.

Retrieved from http://www.econstor.eu/bitstream/10419/34761/1/564786012.pdf

Stadhouders, K. (2015). Steenkuilen en pannebakkerijen. Een Woerdens industrielandschap. In: J. Kolen, H. Ronnes \& R. Hermans (Eds.), Door de lens van de landschapsbiografie. Een nieuwe kijk op de geschiedenis en het erfgoed van landschappen (pp. 193-218). Leiden: Sidestone press.

Steckel, R.H. (1995). Stature and the Standard of Living. Journal of Economic Literature, 33 (4), 1903-1940.

Stable URL: http://www.jstor.org/stable/2729317

Steckel, R.H. (2009). Heights and human welfare: Recent developments and new directions. Explorations in Economic History, 46(1), 1-23.

DOI: 10.1016/j.eeh.2008.12.001

Tassenaar, V. (2000). Het verloren Arcadia. De biologische levenstandaard in Drenthe, 1815-1860. Capelle a/d IJssel: Labyrinth.

Tassenaar, V. \& Karel, E. (2016). The power of the Kashrut: older but shorter: The impact of religious nutritional and hygienic rules on stature and life expectancy of Jewish conscripts in the early 19th century. European Journal of Clinical Nutrition, 70, 667-670.

DOI:10.1038/ejcn.2016.24

Vandezande, M. (2012). Born to die: Death clustering and the intergenerational transmission of infant mortality, the Antwerp district, 1846-1905. (Doctoral dissertation). Retrieved from Katholieke Universiteit Leuven.

Verdoorn. J.A. (1981). Het gezondheidswezen te Amsterdam in de 19e eeuw. Nijmegen: Socialistische Uitgeverij Nijmegen.

Verstoep, C. (1989). Een vrouwenambacht van moeder op dochter doorgegeven: Boerenkaasbereiding in Midden-Nederland, circa 1895-1940. In: F. Backerra, L. Flapper, \& A. Hobbelink (Eds.), Vrouwen van het land. Anderhalve eeuw plattelandsvrouwen in Nederland (pp. 66-78). Zutphen: De Walburg Pers.

Vries Robbé, A.A.C. de (1872). Rapport der commissie belast met het onderzoek naar de toestand der kinderen in fabrieken arbeidende. 's-Gravenhage: Ter Algemeene Landsdrukkerij.

Wells, J.C. \& Stock, J.T. (2011). Re-examining heritability: Genetics, life history and plasticity. Trends in Endocrinology \& Metabolism, 22(10), 421-428.

Zanden, J.L. van \& A. van Riel (2004). The Strictures of Inheritance: The Dutch Economy in the Nineteenth Century. Princeton: Princeton University Press. 